\title{
Use of ICT as a Significant Factor for Formation of Readiness for Realization of Professional Self- Determination of Future Teachers
}

\author{
Tetiana Forostovska $1 *$ [0000-0001-9353-4017], \\ Oksana Lypchanko-Kovachyk 2 [0000-0003-3419-1717]
}

\author{
${ }^{1}$ Volodymyr Vynnychenko Central Ukrainian State Pedagogical University, Kropyvnytskyi, Ukraine \\ ${ }^{2}$ Mukachevo State University, Mukachevo, Ukraine \\ *forostovskaja67@gmail.com
}

\begin{abstract}
In current conditions of educational reforms in Ukraine, the role of a teacher as an active subject of the pedagogical process is increasing, together with requirements towards his personal and professional qualities. Along with high professional competence, a modern school needs a teacher with a high level of professional self-determination, with an awareness of professional responsibility for the education of the youth. Professional self-determination is extremely important for personal and professional growth of future teachers, and also decisive in the process of their professional self-realization. For effective formation of readiness for professional self-determination of future teachers, they should be involved into the use of information and communication technologies during their professional training, since it provides innovative orientation of educational process, promotes the ability to self-study and self-improvement in professional sphere. The research results concerning the impact of ICT on the formation of readiness for implementation of professional self-determination of future teachers indicate that those students who actively use ICT are characterized by a significantly higher level of readiness for professional self-determination. The growth of the index of readiness for professional self-determination within such students occurs more effectively, compared to students who do not use ICT. Higher cognitive independence and higher activity demonstrate those students who use ICT.
\end{abstract}

Keywords: information and communicative technologies, professional self-determination, future teachers, professional training.

\section{INTRODUCTION}

Present-day society requires creative, qualified specialists with a high level of professional selfdetermination, who are also able to solve their professional problems creatively; to obtain professional knowledge individually; to implement obtained knowledge in various situations. From this respect, higher educational establishments are strongly expected to train teachers, who are ready to professional selfdevelopment and actualization of own potential capacity in creative activity.

Process of professional self-determination and formation of a personality as a professional is a longlasting and multi-stage period [1]. After graduating from a higher education institution, a young specialist needs a lot of time and effort to adapt to the conditions of professional activity. One of the reasons concerning this problem is neglecting necessary attention to assessment of the state of professional self-determination at the stage of study in higher educational establishment. One of the leading tasks of professional training lies in teaching a student as a future specialist to self-determine, to form the necessity for self-determination.

A wide range of organizational and pedagogical conditions must be carefully elaborated in order to realize professional self-determination of future teachers. Among these significant conditions the formation of information and communicative competence is extremely urgent (ICT-competence). A future teacher should properly orient in information area, possess knowledge and skills necessary for searching, processing 
and storing the information. Mastering the properties mentioned above provides effective professional activity.

ICT in teaching has an important role and its impact on the advancement of educational processes is related to effective teaching and learning, and modern research in this field is almost irreplaceable [2].

Modern informatization of the system of education meets the challenges towards effective use of electronic educational resources with a view to build up educational process and to organize the interaction of all subjects in this process. The basis of educational process is not only the acquisition of knowledge, but also ways and means of their implementation, the development of individual abilities of students.

We live in a world where we are exposed to everyday changes that information and communication technologies (ICT) give us impose. These changes are largely related to education, and so the introduction of ICT in universities as institutions of higher education, clearly changing the way it is implemented [3].

\section{RESEARCH METHODOLOGY}

A modified variant of V. Radul's [4] methods for formation of individual's social maturity has been applied by the authors of the present article in order to develop and implement the methods of formation of preparedness to professional self-determination of future teachers. The algorithm of considered technique is based on the idea of the primary combination of numerous selfassessments and assessments made by experts into an integrated indicator - a numerical index.

Development of methods for formation of readiness for professional self-determination requires the development of sociological tools (questionnaires, interviews, etc.) based on the scheme of logical replacements, which is traditionally used to describe individual activities.

The first stage of experiment made it possible to distinguish two groups: experimental and control. Experimental groups contained the notions of intensive influence upon formation of readiness to professional self-determination of a future teacher, namely involvement of students into the use of information and computer technologies. Special stimuli (types of activities) of involving students have been organized. At the same time, the mentioned above stimuli have not been applied in control groups.

Experience of forming readiness for professional selfdetermination of students in experimental and control groups has been recorded applying methods of mathematic statistics.

Numerical value of the index of readiness for professional self-determination has been distinuguished by combination of both: 1) student's self-assessments and assessments he gave to his fellow-students; 2) expert assessments. The selected statements of compiled questionnaire under the title "self-assessment", which is filled in by respondents, have also been complemented by assessments of experts (teachers, monitors of academic groups, faculty deans, fellow students) in accordance with formulated questions. This technique involves comparative analysis of own answers, that is self-assessment with assessments by experts.

Through comparison and generalization of obtained data we have worked out the stereo questionnaire and the form-sheet for expert estimation which contains parameters of self-sufficiency and activism of a future teacher.

Opinions of numerous experts have been taken into consideration for objective evaluation of indicators that indicate the formation of readiness of professional selfdetermination of a future teacher.

Peculiarities of formation of readiness of professional self-determination have been being studied by us starting from 2016 until 2020. During this period, students from different pedagogical institutions of higher education in Ukraine have been diagnostically tested. Generally, more than 420 respondents have been involved into experiment.

\section{ISSUE DISCUSSION}

Readiness of a future teacher to professional selfdetermination is an integrated characteristic feature of a professionally mature personality, being able to develop individually, distinguishing by personality's own activism, goal-oriented changes, developing and transforming own activity.

External position in determination of readiness of a future teacher for professional-determination is future teacher's identity. Among those criteria which enable to record varied changes of investigated readiness of future teachers the authors have selected the following: professional cognitive independence and activism. Elaborated criteria possess qualitative essence and appropriate indicators of expression.

Quantitative criteria which have been introduced in work under consideration are experimentally determined interval indicators of indices of cognitive independence and activism. Variants of their intersection form particular levels of formation of readiness for professional self-determination of a student. Experimental values of each index range from 1 to 5 . We have singled out three intervals of numerical values of index - "socio-creative" (high) (5.0-4.01), "personality and activity-oriented" (average) (4, 0-3.01), "situational" (low) (3.0-1.5). Boundaries of these intervals characterize a certain level of formation of readiness for professional self-determination of future chemistry 
teacher. The level has quantitative and qualitative explanation.

In the era of development of global computer network Internet a teacher-to-be must promptly update his professional knowledge throughout his professional activity. A future teacher has to be able to learn and apply new forms, methods and teaching aids, to improve his information culture and develop information and communication skills.

Implementation of system of information, communicative and instrumental means made it possible to change traditional scheme of organization the training process of a future teacher providing theoretical development and practical realization of varied structure of educational process of higher educational establishment.

Second section has testified, that generalized index of readiness for professional self-determination of students, who have been involved in the use of ICT in professional training increases significantly in comparison with those students who have not been involved in such activity. Comparative information is presented in Table 1.

Table 1. Total indicator of indices of readiness for professional self-determination of student groups involved and not involved into the use of information and communicative technologies in professional training. Dating February, 2020.

\begin{tabular}{|c|c|}
\hline $\begin{array}{c}\text { Students involved } \\
\text { into the use of ICT in } \\
\text { professional training } \\
(\mathrm{H}=45 \text { people })\end{array}$ & $\begin{array}{c}\text { Students not involved } \\
\text { into the use of ICT in } \\
\text { professional training } \\
(\mathrm{H}=45 \text { people })\end{array}$ \\
\hline 3,69 & 2,82 \\
\hline
\end{tabular}

Comparative analysis of obtained data shows that the index of readiness for professional self-determination of students being involved in the use of ICT is closely correlated with the intensive growth of their readiness for professional self-determination. Students in control group are characterized by lower growth rates of mentioned readiness. The results of comparative analysis are presented using distribution frequency of readiness for professional self-determination (Figures 1-2).

Obtained data, which have been presented in Figures 1-2, testify that between the frequency distribution of readiness for professional selfdetermination of experimental and control groups there is a certain difference in the interval indicators of indices of readiness for professional self-determination of future teachers. Diagnostic testing in 2017 has showed that experimental group is characterized by such a numerical indicator of index of readiness for professional selfdetermination - 3.0-3.5. As far as diagnostic section of the year 2020 is concerned the top of its positive values falls into the range of 3.5-4.0. Concerning index designations of readiness for professional selfdetermination of students who have been involved in the use of ICT in professional training, both groups demonstrate similar numerical interval 2.5-3.0. This proves a difference in the level of expression of the future teachers' readiness for professional self-determination of students in both groups.

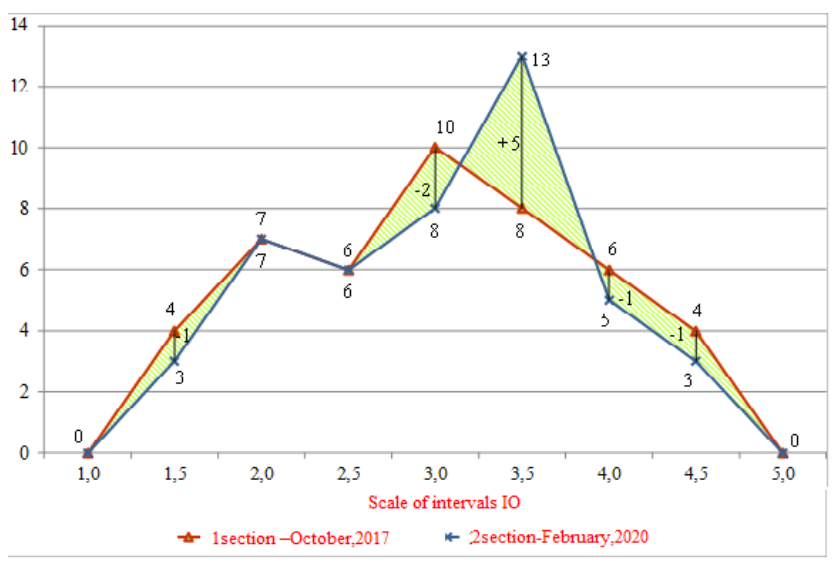

Figure 1 Frequency distribution of students in experimental group with indicated intervals of index of readiness for professional self-determination

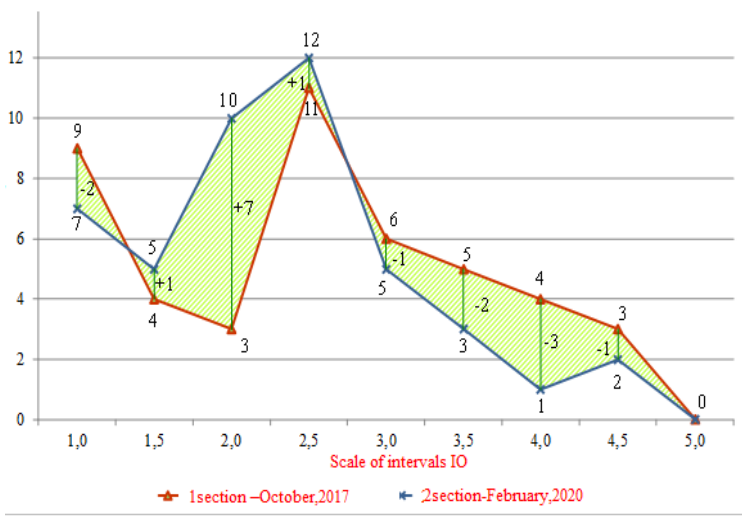

Figure 2 Frequency distribution of students in control group with indicated intervals of index of readiness for professional self-determination

Active encouraging of future teachers to use ICT is closely correlated with the intensive growth of their readiness for professional self-determination. Students in control group are characterized by lower growth rates of investigated readiness. The use of ICT by a future teacher in professional training is an effective pedagogical condition for the formation of their readiness for professional self-determination.

Thus, modern ICT in the process of professional training of future teachers increases the efficiency of educational process in the context of both - traditional and innovative education systems. They provide the development of skills of future professionals for selfstudy and self-improvement in professional sphere, as 
well as develop the ability to acquire themselves the necessary knowledge.

Using Figures 3-6, the analysis of frequency distributions of experimental and control groups according to the indices of their cognitive autonomy and activity have been presented.

Innovative direction of teaching activity has been caused by ICT, the basic task of which lies in the development of something new, that provides efficiency of educational process. Eventually, in information society, an important problem remains not in idea to obtain qualification in the chosen field, but to obtain and develop certain skills that should enable future teachers to adapt to dynamic development in future professional activity.

Information in Figures 3-4 represents the results of diagnostic tests of independence of future teachers. Obtained results testify, that independence is relatively higher within a group of those students who use ICT in professional training. The students of experimental group have demonstrated the index of their independence by interval 4,0-4,5, meanwhile students of control groups $3,0-3,5$.

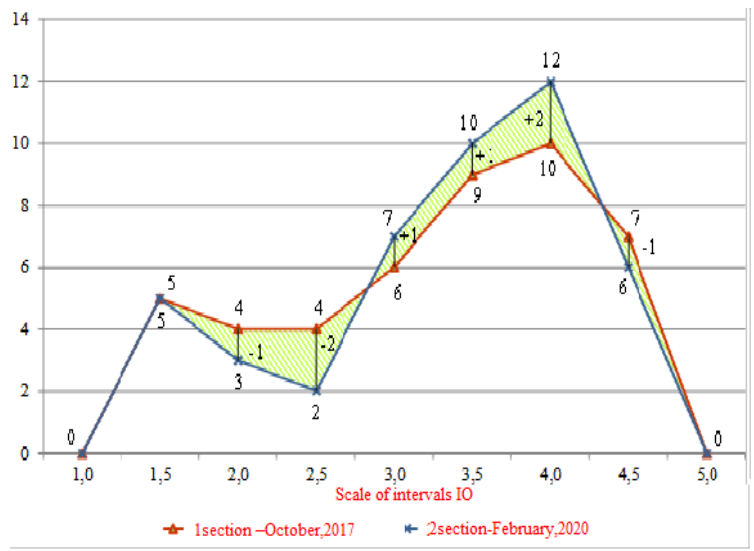

Figure 3 Dynamics of frequency distribution of students of experimental group according to the index of independence

Information and communication technologies of teaching make it possible to increase the quality of organization of self-educational activity of students, creating a comfortable information-communicative pedagogical environment, which is a means for development of self-educational competence of future teachers [5].

Thus, the use of information and communication technologies affects significantly upon cognitive independence of future teachers, where under urgent importance remains cognition through one's own independent search, awareness of information and ability to use acquired knowledge in new social conditions.

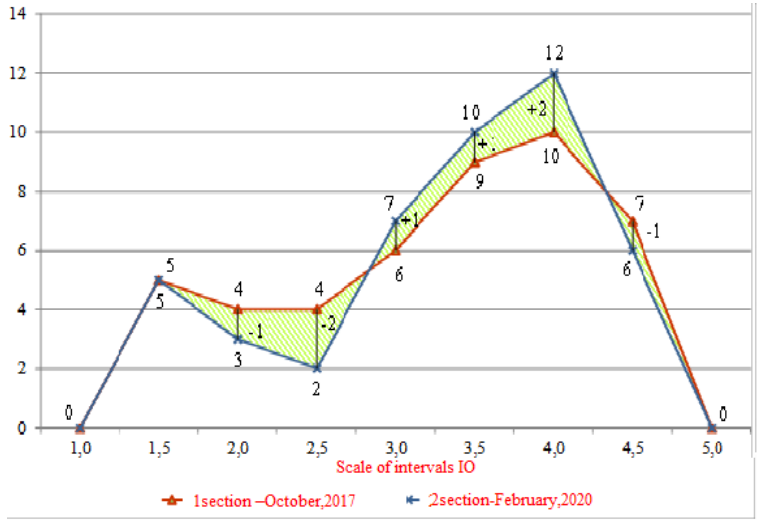

Figure 4 Dynamics of frequency distribution of students of control group according to the index of independence

The indices of activity of students of experimental group fall into the numerical range from 4.0 to 4.5 , meanwhile control group from 2,0 to 2,5 (Figures 5-6).

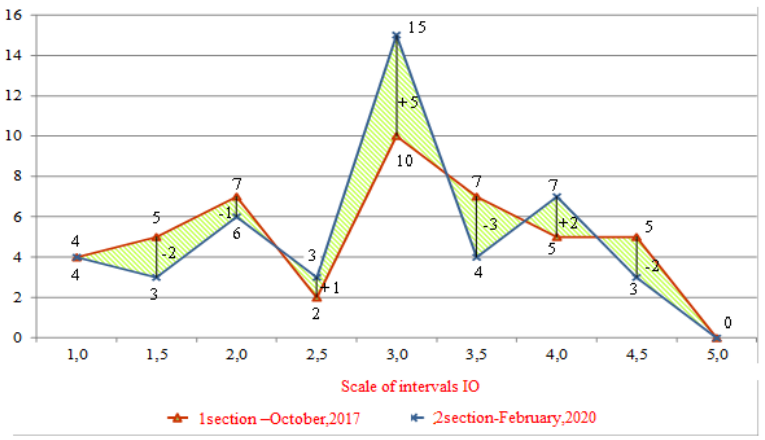

Figure 5 Dynamics of frequency distribution of students of experimental group according to activity index

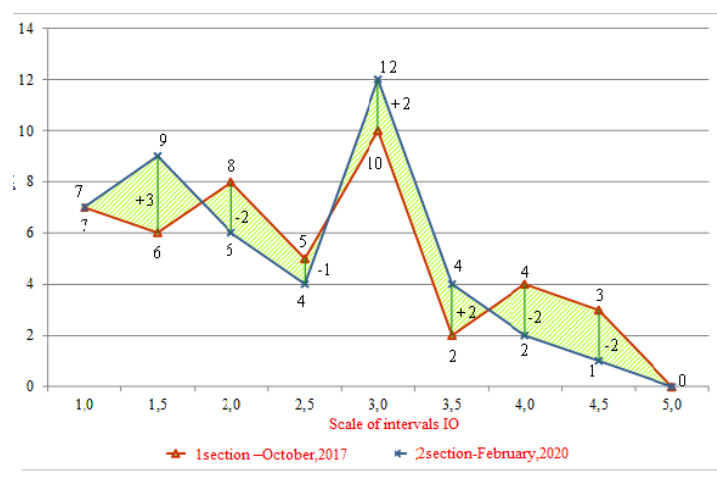

Figure 6 Dynamics of frequency distribution of students of control group according to activity index

Obtained results indicate that activity is much higher in groups of students who are involved in the use of ICT while training. That is, information and communication technologies significantly affect the formation of activism of future teachers.

Carried out research has stressed upon the necessity of the use of ICT in professional training of future teachers with a view to form their readiness for professional self-determination. 


\section{RESULTS}

We live in a world where we are exposed to everyday changes that information and communication technologies give us impose. These changes are largely related to education, and so the introduction of ICT in universities as institutions of higher education, clearly changing the way it is implemented [6].

General and professional competencies of a future teacher are being formed in the process of implementation of traditional forms of study as well as in the process of student's independent learning activity, including the use of ICT.

In terms of using information and communication technologies, information and educational basis of higher educational establishment appears to be a significant factor in the formation of readiness for professional selfdetermination, which supports organization of fundamentally new professional training of a teacher and affects the formation of future professional trajectory of a student. The use of ICT enables educational institutions to change fundamentally their teaching and learning environment. Therefore, their development and implementation have become the dominant direction of numerous investments [7].

From this respect, electronic educational and methodological complex has proved to be the effective means of organization and support of educational process in higher educational establishments. In particular, we recommend students a developed software for educational intended use, consisting of the following blocks: theoretical, practical, diagnostic and control which is at disposal on the platform Moodle [8]. This multimedia educational complex provides possibility to support a student with necessary material in real time and with demanded speed. It also provides easy access to any sort of information, creates an integrated idea about subject and makes it possible to choose the trajectory, which is especially relevant for distance education. Distance education can be very effective use of instructional materials with visual, auditory, audiovisual and multimedia content [9].

It is worth indicating that, despite high potential of modern ICT, complex e-learning tools are of limited use in the process of study of academic disciplines, due to the lack of certified virtual tools. In the era of Information and Communication Technology (ICT), virtual laboratories in the field of engineering and sciences have gained popularity, as a smart way of imparting practical and theoretical education [10].

In the future, during the professional-oriented stage, students practically use the acquired knowledge and skills, in the process of developing lessons, extracurricular activities, creating digital educational resources, knowledge control systems, visual aids, educational projects etc.
At the same time, the latest information and communication technologies should not displace the traditional system of education, they should complement and strengthen each other. It is this precise integration that contributes to improvement of the quality of training of future teachers, the formation of readiness for professional self-determination.

\section{CONCLUSIONS}

Investigation results of the influence of ICT upon the formation of readiness for realization of professional self-determination of future teachers have clarified that those students who permanently use ICT, are characterized by a relatively higher level of readiness for their professional self-determination. The growth of the index of readiness for professional self-determination within such students occurs more effectively, compared to students who do not use ICT. Пізнавальна самостійність та активність вища у тих студентів, які використовують IКТ. Thus, cognitive independence and activity of students, future teachers in higher educational establishments are formed by means of ICT.

\section{REFERENCES}

[1] Galustyan, Olga V. Solyankina, Lyudmila E. Slobotchikov, Oleg N. Kuleshov, Sergey M. and Solyankin, Alexey V. (2019), "Professional and Career Consulting as a Factor of Professional Selfdetermination of the Youth", TEM Journal, Vol. 8 , Issue 3, pp. 1071-1075.

[2] Bekim Fetaji, Majlinda Fetaji, Mirlinda Ebibi and Samet Kera (2018), "Analyses of Impacting Factors of ICT in Education Management: Case Study", International Journal of Modern Education and Computer Science, Vol. 10, No. 2, pp. 26-34.

[3] Mirjana Kocaleva, Igor Stojanovic and Zoran Zdravev (2015), "Model of e-Learning Acceptance and Use for Teaching Staff in Higher Education Institutions", IJMECS, Vol. 7, No. 4, pp. 23-31.

[4] Radul, Valerii V. Haleta, Yaroslav V. Liashenko, Rostyslav O. Radul, Olha S. and Tkachenko, Olha (2020), "Social maturity as integrative quality of young teacher's personality", Astra Salvensis, pp. 235-251.

[5] Pyetukhova, L.Y. and Voropay, N.A. (2011), Informatsiyno-komunikatsiyni tekhnolohiyi yak zasib formuvannya samoosvitnoyi kompetentnosti [Information and communication technologies as a means of formation of self-educative competence], Pedahohika $i$ psykholohiya, Chernivtsi: Chernivets'kyy nats. u-t.

[6] Mirjana Kocaleva, Igor Stojanovic, Zoran Zdravev (2015), "Model of e-Learning Acceptance and Use 
for Teaching Staff in Higher Education Institutions", IJMECS, Vol. 7, No.4, pp. 23-31.

[7] Qi B., Liu L. and Wang Ch. (2009), "E-learning Tools to Improve Students' Learning Experience: a case study". Int. J. Modern Education and Computer Science, Vol. 1, no. 1. pp. 1-9.

[8] Bokhan, Y.V. Forostovska, T.O. (2019), Osoblivosti vykladannya kursu «Zahalna ta neorganichna khimia» $v$ profesiyniy pidhotovtsi maybutnikh vchyteliv pryrodoznavchykh dystsyplin [Peculiarities of teaching discipline "General and neorganic chemistry" in professional training of future teachers of nature science disciplines], Naukovyy visnyk lyotnoyi akademiyi. Seriya: Pedahohichni nauky, Kropyvnytskyy.

[9] Bogdanović, M. (2012), "Growing Importance of Distance Education", Int. J. Modern Education and Computer Science, Vol. 4, No. 3, pp. 35-41.

[10] Vaibhav Gautam and Roop Pahuja (2015), "Webenabled Simulated and Remote Control Virtual Laboratory of Transducer", IJMECS, Vol. 7, No. 4, pp. 12-22. 